\title{
Karawaci Conference on Christian Response to Global Heath
}

\section{Issues}

\section{Rev Morris Sing Key ${ }^{a}$}

${ }^{a}$ representing the Conference Steering and Organising Committees

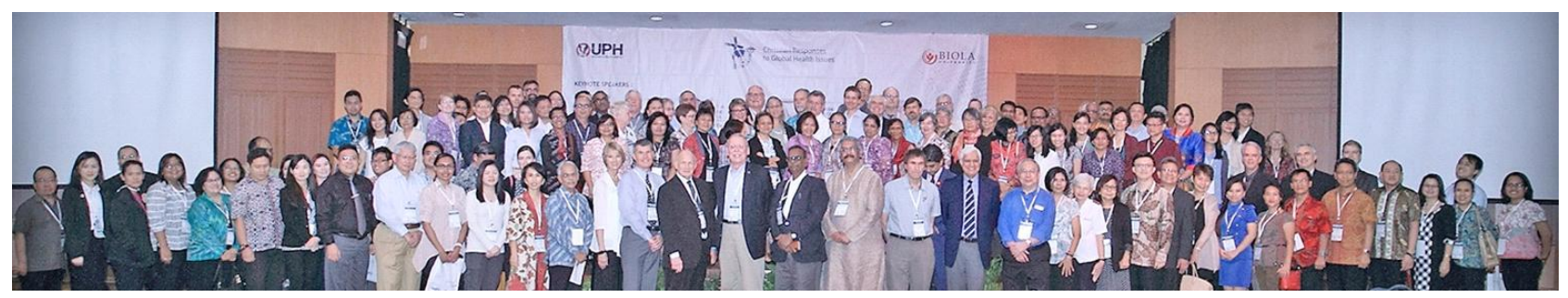

\section{Conference}

The International Conference on Christian Response to Global Heath Issues co-hosted by Biola University (USA) and the Universitas Pelita Harapan (UPH, Indonesia) was held in the UPH campus, Karawaci, from December 2-4, 2015 in Jakarta, Indonesia.

This conference was designed to bring together healthcare workers from a variety of backgrounds, ranging from chaplaincy, bioethics, academics, as well as those working with economic disparity and emerging healthcare issues. Thus, Christians involved in theology, bioethics, cutting edge technology, and research in prevention, cure, and quality of life improvement came to share and present their experiences. There was significant representation from major Christian healthcare missionary organizations, internationally renowned theologians, and academics in bioethics and clinical pastoral care. Christian healthcare workers from 13 different countries participated. Around 300 fulltime and part-time delegates attended the conference over two days.

The conference opened on the afternoon of Dec 2nd, with the leaders prayerfully setting the tone for the conference with opening addresses that challenged the participants to think together on the importance of Christ-centered healthcare in response to needs across the world today. This was followed by Indonesian cultural entertainment by UPH students and an opportunity for all delegates to meet one another informally over dinner.

Themes for Key Note addresses, Oral Presentations, Breakout Sessions, and Panel Discussions

1. Christian response to emerging Global Health issues

- Emerging infections-Ebola/Resistant Malaria/Dengue

- Epidemics in resource-poor countries

- Response to natural and man-made disasters

2. Christian response to medical care in resourceconstrained and economically-challenged environments

- Quality vs quantity

- Low cost effective care

- Appropriate innovations and technologies

- Compassion fatigue serving and working in remote and isolated areas

3. Christian response to emerging technologies and treatment

- $\quad$ Stem cell research

- Human cloning

- Genetic engineering

- Artificial reproduction/surrogacy 
4. Christian response to incurable disease, pain and dying

- Cure vs healing

- Meaning of suffering

- Palliative care

- Care of the dying

\section{Christian response to emerging Global Health issues}

Dr Ravi Zacharias, followed by Dr Tim Teusink, spoke on the importance of being human from a Biblical perspective, i.e., man made in the image of God. Dr Ravi challenged our world view, through the eyes of God, where suffering and pain can be understood, and forgiveness and hope are possible. Dr Tim reminded us that our faith must transcend popular "individualism," both secular or religious, to value people because of their intrinsic worth in God. That way, men, women, and children can all be honored: the sick are cared for and the elderly enabled to live and die with dignity; dissidents are heard; prisoners are rehabilitated; minorities are protected; and the oppressed set free; where workers are given fair wages and decent working conditions; and the Gospel is taken to the ends of the earth.
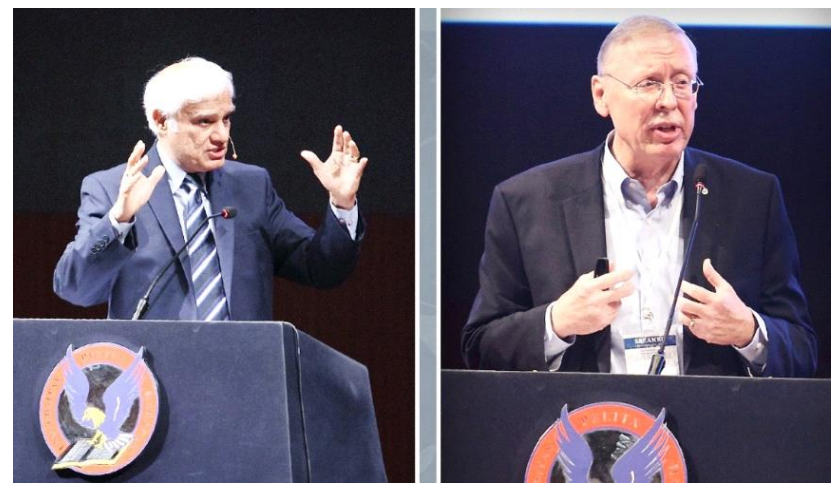

Talks were followed by breakout sessions where speakers from 4 different countries covered the following:

- Emerging health issues: mental health, obesity, human trafficking

- Challenges and responses by Christian healthcare professionals in:

- Natural and man-made disasters
- Compassion fatigue

- Christian education to prepare future workers The session concluded with a stimulating panel discussion on questions from attendees.

Christian response to medical care in resource-constrained and economicallychallenged environments

How should Christian healthcare organisations respond to these limitations?

Dr Mike Soldering and Dr Daniel O'Neill laid out theological foundations for the church's compassionate and effective response to an increasing burden of global disease in resourceconstrained regions. Dr. Soldering challenged us to abandon traditional professionally-guided territories and status and instead to fully harness the skills and strength of every member of the healthcare system to meet the needs of patients. This may mean that doctors may have to surrender some traditional roles to nurses or community healthcare workers.

Talks were followed by breakout sessions on diverse topics given by speakers from six different countries covering:

- insights on how innovation and strategic thinking to involve students and non-healthcare professionals could address economicallychallenged and resource-constrained environments,

- theological and ethnical frameworks in spite of constrained resources, learning from historic missionary examples and insights for the future.

The session concluded with a stimulating panel discussion on questions raised by attendees.

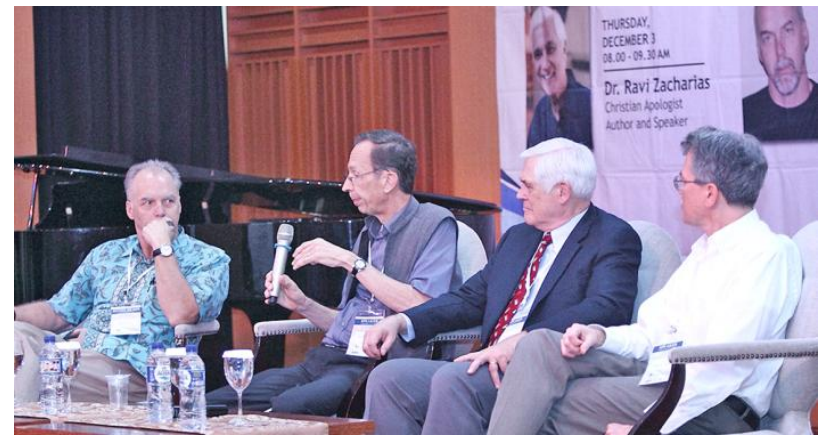




\section{Christian Response to emerging Technologies and Treatment}

Dr. John Lennox spoke on God being the basis of our entire universe. All human discoveries must be governed by God's divine perspective. Dr. Peter Saunders laid out the theological foundations for how Christians must assess all new technologies and treatment in light of the Bible. Both talks challenged us to defend our faith and to seek all available avenues via the legal system and the media to debate ethical issues related to research and new technology in human genetic engineering and manipulation. We were also encouraged to ponder the social and legal impacts of artificial reproduction, surrogacy, and other new biotechnologies and weigh them against biblical teaching.

Breakout sessions on diverse topics followed with speakers from five different countries covering:

- emerging technologies discussed in the light of bio-ethnics: the HIV/AIDS pandemic, stem-cell research and therapy, and 'Child of Choice' technology,

- the importance of collaboration among Christians workers to voice our concerns on these ethnical issues, and

- hallmarks of a Christian healthcare professional and the importance of global coalitions in Christian healthcare education.

The session concluded with a stimulating panel discussion on questions raised by attendees.

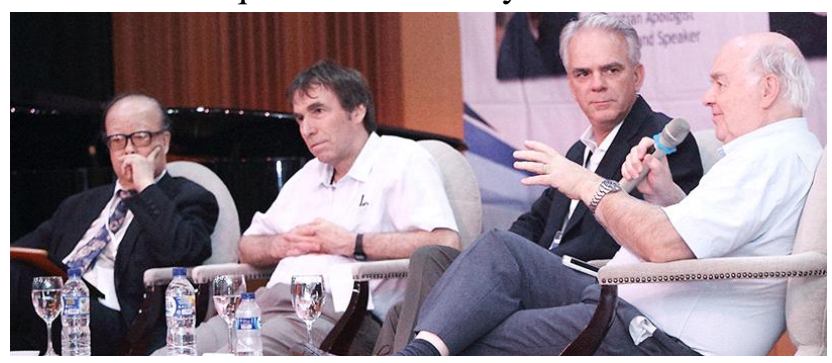

Christian Response to Incurable Disease, Pain, and Dying

Elizabeth Styffe challenged all of us to go and be mobilised, to partner with poorer countries and communities, and to train and empower local Christians to reach out to their communities via healthcare. Dr Reena George shared her personal journey in palliative care and offered important practical tips on managing pain in terminal patients.

Talks were followed by breakout sessions on diverse topics given by speakers from five different countries covering

- a historic account of Christian contributions in palliative care,

- practical examples of palliative care models from Indonesia and Malaysia,

- pastoral care of the dying, and

- partnering with local churches to train lay volunteers to provide basic community healthcare services - The Rwanda model.

The session concluded with a stimulating panel discussion on questions raised by attendees.

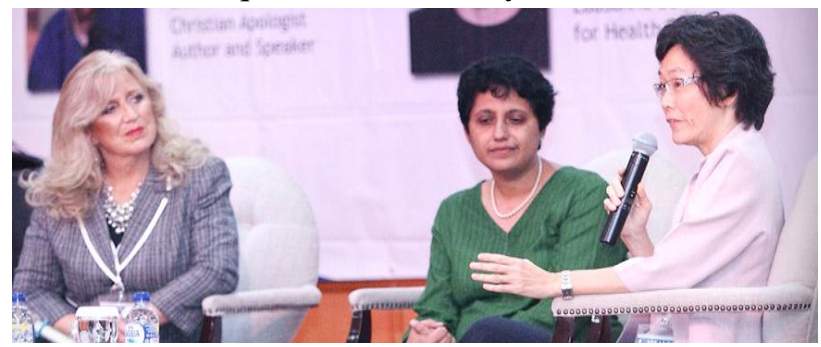

\section{Closing Ceremony and Networking}

\section{Dinner}

The conference concluded on the evening of December 4th with a networking dinner, where fellow attendees enjoyed warm fellowship and a cultural performance by UPH students. Everyone expressed the great need for Christians to meet to encourage one another in our vision and mission, possibly yearly. 


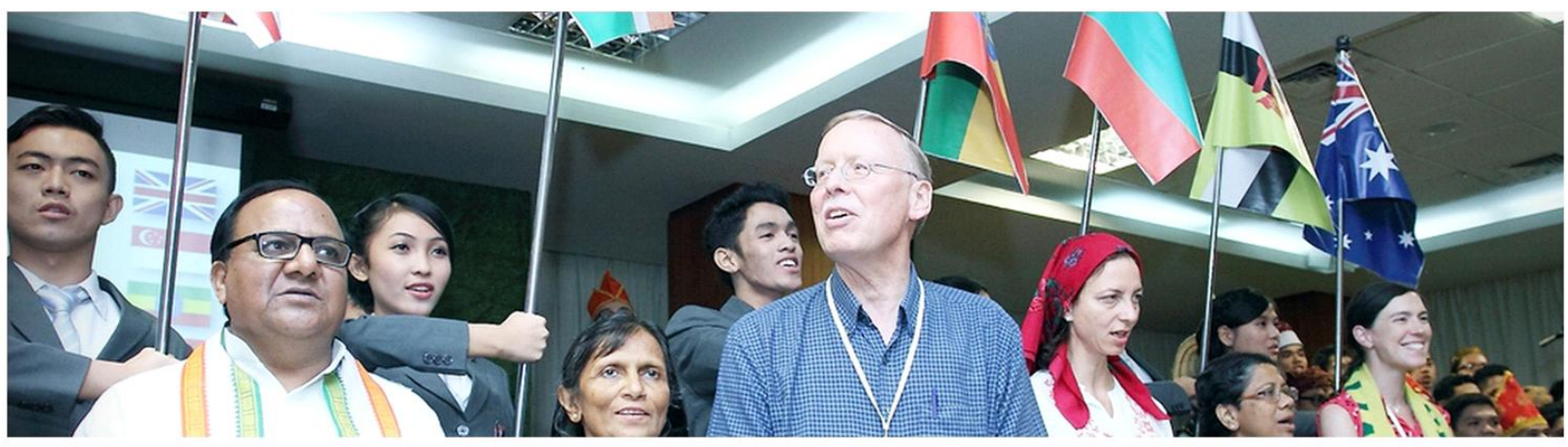

Competing Interests: None declared.

Correspondence: Rev. Morris Sing Key, msingkey@gmail.com

\section{Acknowledgments:}

Conference Steering Committee:

Chair: Prof Dr George Mathew, Co-chair: Dr Doug Pennoyer, Members: Prof Dr Eka Wahjoeprammo, Rev Morris Sing Key

Organising Committee:

Chair: Connie Rasilim, Members: Anita Prasetyo, Indah Kurniawati, Christine L Sommers, Dr Stevent Sumantri, Dr Yusak, Novel Priyatna, Dr Diena Lemy, Esterina Jonathan, Esther I Pubra, Florianna Sing Key, Marta Oktaviani Souhuwat, Rosse Mince Hutapea, Nursari Lugito, Titis Pinasti

Cite this article as: Key MS. Karawaci Conference on Christian Response to Global Heath Issues. Christian Journal for Global Health (May 2016), 3(1): 99-102.

(C) Key MS. This is an open-access article distributed under the terms of the Creative Commons Attribution License, which permits unrestricted use, distribution, and reproduction in any medium, provided the original author and source are properly cited. To view a copy of the license, visit http://creativecommons.org/licenses/by/3.0/

$$
\text { www.cjgh.org }
$$

May 2016. Christian Journal for Global Health, 3(1):99-102. 